\title{
VEZETŐI DÖNTÉSHOZÁS A TEJTERMELŐ ÁGAZAT FOGLALKOZTATOTTI ELÉGEDETTSÉGÉBEN A BAJAI JÁRÁSBAN
}

\author{
Gulyás Dóra Kinga - Fodor Fanni Ildikó - Thalmeiner Gergő
}

\section{Összefoglalás}

A magyar szarvasmarha ágazat mezögazdaságunk egyik legsikeresebb ágazata volt egészen a rendszerváltás ellöttig. A rendszerváltást követöen az ágazat átstrukturálódott, nagymértékben megváltoztak a tulajdonviszonyok, a müködö telepek egy részén pedig felhagytak a termeléssel. Hazánkban müködö vállalkozások és kiemelten a munkaeröhiányban szenvedö mezögazdasági szervezetek esetében a termelékenység növelése az egyik legfontosabb cél. A humán eröforrás menedzsment és azon belül a foglalkoztatotti motiváció-, elégedettség mérése és menedzselése pedig a vállalati funkciók közül az egyik olyan kiemelkedö tényezö, amelynek hatékonysága a szervezetben lévö összes gazdálkodásszervezési folyamat-, termelékenység szintjét növeli.

Kutatásunk során azt vizsgáljuk, hogy a bajai járásban lévö tejtermelö tehenészet ágazatában müködö vállalkozások által foglalkoztatott munkavállalók elégedettségi érzete milyen, és mindez milyen hatással van a szervezetek müködésére. Valamint szeretnénk feltárni azokat a befolyásoló hatással biró tényezöket, melyek segitségével rálátásunk nyilhat, hogy mennyire motiváltak és elégedettek a foglalkoztatottak a vizsgált ágazatban.

Kulcsszavak: tejtermelo" tehenészet, termelékenység, humán eröforrás, elégedettségi érzet, bajai járás

JEL: Q10

DOI: $10.33032 /$ acr.2019.9.1.81 


\title{
LEADERSHIP DECISION MAKING IN THE DAIRY INDUSTRY EMPLOYEE SATISFACTION IN BAJA DISTRICT
}

\begin{abstract}
The Hungarian dairy cowshed sector was one of the most successful sectors of our agriculture until the change of regime. Following the change of regime, the sector was restructured, property ownership changed to a large extent, and production was abandoned in some of the operating sites. In the case of companies operating in Hungary and especially agricultural organizations suffering from labor shortages, increasing productivity is one of the most important goals. Measuring and managing human resource management and, in particular, employee motivation, satisfaction, is one of the outstanding features of corporate functions, whose efficiency increases the level of process management and productivity in the organization. In our research, we investigate what kind of satisfaction the employees of the enterprises in the dairy cowshed sector in Baja district have and what impact this has on the functioning of the organizations. We also want to explore the influencing factors that can help us see how motivated and satisfied our employees are in the sector under investigation.
\end{abstract}

Keywords: dairy cowshed, productivity, human resource, satisfaction feeling, baja district

JEL: Q10 


\section{Bevezetés}

Magyarországon a rendszerváltást követően folyamatos a gazdasági átalakulás, a megváltozott piaci viszonyok a mezőgazdaság és az élelmiszeripari termelés nagymértékű visszaesését eredményezte. A nemzetközi piacok elvesztése, a hazai fogyasztás változása szerkezetváltásra, korszerűsítésre sarkalta az ágazat szereplőit, ami jelentős foglalkoztatási átalakulással is járt. Az állattenyésztési ágazatok termelés jövedelmezősége visszaesett, mivel a termelési költségek növekedését csak részben tudta kiegyenlíteni az élő állatok és az állati termékek lassabban növekvő árszintje. Az EU-csatlakozást követően a hazai termelésű állati eredetű élelmiszerek aránya a lakossági fogyasztásban (a közösségivé vált belpiacra beáramló külföldi termékek miatt) jelentősen csökkent, kivitelük viszont nem nőtt (Kapronczai, 2011). Az állattenyésztő ágazat azon belül is a tejelő szarvasmarha tenyésztés visszaszorulása a hazai agrárágazat jövőjének egyik legjelentősebb problémája, amely napjainkban is megoldásra vár. Az ágazat helyzetének folyamatos hanyatlásának visszafordítása összetett feladat, mivel a nehéz helyzet mögött komplex, versenyképességi, jövedelmezőségi, finanszírozási, hatékonysági és jogszabályozási okok találhatóak. A tejelő szarvasmarha ágazat versenyképességének javítása többek között azért is számít különösen fontos feladatnak, mert az ágazat jövőbeni sikerességét a különböző forrású támogatási összegek egyre kevésbé fogják befolyásolni és nem csak kifejezetten az agrárpolitikai változások határozzák meg, hanem egyre jelentősebben a piaci hatások és az egyre inkább globalizálódó világpiaci folyamatok határozzák meg az ágazat jövőbeni sikerességét (Illés B. Cs. et al., 2014).

\section{Szakirodalomi áttekintés}

Magyarország mezőgazdaságára jellemző a gyenge versenyképesség, a technológiai elmaradottság, valamint a szervezési- irányítási hiányosságok. Többek között ezek miatt is az ágazat relatív visszaszorulása az elmúlt időszakban jelentős volt. A rendszerváltás előtt, 1989-ben a mezőgazdaságban az aktív keresők 17,3\%-át foglalkoztatták, míg 2017-ben megközelítőleg már csak 5,0\% volt a mezőgazdasági foglalkoztatás részaránya. Ugyanezen időszak alatt a mezőgazdaság részesedése a GDP-előállításból 13,7\%-ról 3,3\%-ra csökkent (Kovács, 2010). A 2017-es évben a mezőgazdaság teljes bruttó kibocsátásából a szolgáltatás és másodlagos tevékenység 7,5\%-os részaránya mellett, a növénytermesztési és kertészeti termékek együttesen 58,1\%-ot képviselnek, míg az élő állatok és állati termékek összesen 34,4\%-os részesedéssel rendelkezik. 
A munkaerő-ráfordítás nagysága 426 ezer ember teljes munkaidős tevékenységének felelt meg, ami 1,9\%-kal maradt el a 2016-os évhez viszonyítva. A mezőgazdasági termelői árak összességében 5,6\%-kal emelkedtek, ezen belül a növényi termékek termelői ára 3,3\%-kal, az állatok és állati termékek termelői ára 9,3\%-kal növekedtek (KSH, 2017).

Kiemelten az állattenyésztésen belül a szarvasmarha-ágazat a bruttó hazai össztermék jelentős részét adja, a sertés- és a baromfiágazatot követően a harmadik legnagyobb volumenű állattenyésztési ágazatként nevezhető. Jelentős szerepet képvisel a táj- és környezetvédelem, a településszerkezet és foglalkoztatáspolitikai összefüggései révén az egész nemzetgazdaságban. Nem túlzás tehát azt állítani, hogy stratégiai jelentőségű ágazat, „a mezőgazdaság nehézipara” (Stefler et. al., 1995). Aktuális statisztikai adatok alapján a tej ágazat kibocsátása 2016-ban 145,1 milliárd forint volt, a mezőgazdaság kibocsátásának 5,5\%, az állattenyésztés kibocsátásának 16,8\%-a. A kibocsátás folyó áron egy év alatt 6,1\%-kal csökkent, ennek egyik legfőbb oka az, hogy az árak csökkenésének nagysága meghaladta a volumen kismértékü növekedését.

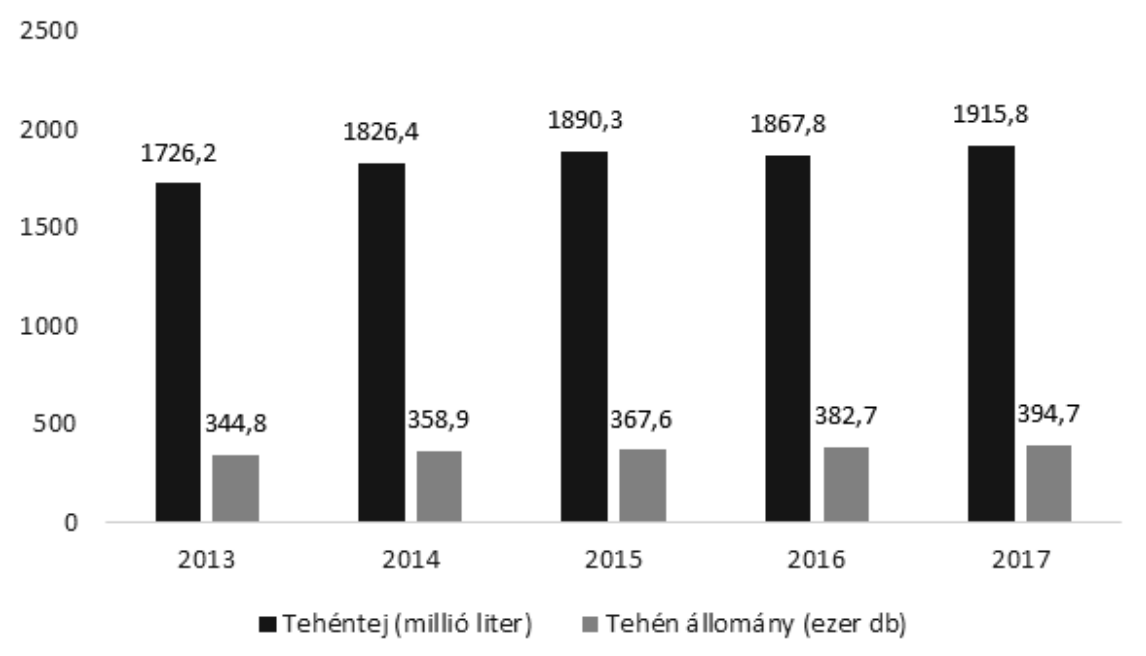

1. ábra Tehéntejtermelö ágazat helyzete

Forrás: Saját szerkesztés (KSH, 2017) adatok alapján, 2018

A tehéntejtermelő ágazat helyzete elnevezésű ábráról leolvasható, hogy az elmúlt években nem változott jelentősebben a tehén állomány létszáma, csak minimális növekedés figyelhető meg a mutató értékében. A tehénállomány létszámának minimális növekedésével arányosan a tehéntejhozam mutatójának is kismértékü növekedése figyelhető meg a vizsgált években. 
Összességében elmondható, hogy a szarvasmarha ágazat egy kézimunkaerőt igénylö ágazat. Annak érdekében, hogy a munkatermelékenységet növelni lehessen objektív és szubjektív szempontú tényezőket is figyelembe kell venni. Az objektív csoportba tartoznak a termelőeszközökkel kapcsolatos feltételek, a tartás természeti feltételei, valamint a gazdasági-társadalmi tényezők. A szubjektív csoportba sorolandók: a tudományos eredmények implementálása, a dolgozók szakképzettsége és az ösztönzési formák.

A tejtermelés versenyképességét a telepek eszköz felszereltsége, azon belül is a műszaki-technológiai háttér jelentősen meghatározza (Horváth, 2004). A versenyképesség javítása úgy lehetséges, ha a vállalkozások az eszközeiket, amelyek elöregedtek vagy túlhasználtakká váltak mennyiségi és minőségi szempontból egyaránt fejlesztik (Husti, 2003). A versenyképesség mellett a munkatermelékenységet is erősen befolyásolja a termelés technológiai színvonala, mint például a fejőkehely eltávolítása vagy a fejőberendezés típusa (Geszti - Borbély, 2004). Ezekből következően elmondható, hogy az élőmunka kiváltására abban az esetben vállalkozhatnak a termelők, ha technológiájuk korszerü. A következőekben az egy tehénre jutó munkaóra-felhasználásra szemléltet példát az 1. táblázat.

\begin{tabular}{|l|c|c|c|c|}
\hline Megnevezés & 1999 & 2000 & 2001 & 2002 \\
\hline EDF & 52 & 55 & 47 & 39 \\
\hline $\begin{array}{l}\text { Németország keleti } \\
\text { tartományai }\end{array}$ & 45 & 48 & 47 & 43 \\
\hline Magyar & 109 & 98 & 98 & 95 \\
\hline
\end{tabular}

1. táblázat Az egy tehénre jutó munka mennyisége (h/tehén)

Forrás: (Geszti-Borbély, 2004)

Elmondható, hogy a magyarországi magasóraszám az eszközök korszerűtlenségéből, termelő alapok leromlásából, az alacsony munkaidő-kihasználtságból és a rossz munkaintenzitásból tevődnek össze. A mutatók növelése érdekében célszerű az eszközök korszerűsítés, beruházások végzése, melyekkel kézimunkaerőt lehetne kiváltani adott munkafolyamatok elvégzésekor, továbbá a munkavégzés precizitása is javulna.

A 2. táblázat jól szemlélteti, hogy a tehénlétszám növekedésével az egy tehén gondozására jutó éves munkaóra mennyisége csökken (Vadász, 1965). 


\begin{tabular}{|l|l|l|l|}
\hline $\begin{array}{l}\text { Tehénlétszám } \\
\mathrm{db}\end{array}$ & $\begin{array}{l}\text { A vizsgált üzemek } \\
\text { száma }\end{array}$ & Átlagos tehénlétszám & $\begin{array}{l}1 \text { tehénre jutó } \\
\text { munkaidő évente } \\
\text { (óra) }\end{array}$ \\
\hline $1-49$ & 237 & 20 & 420 \\
\hline $50-99$ & 50 & 72 & 372 \\
\hline 100 felett & 52 & 168 & 340 \\
\hline
\end{tabular}

2. táblázat A tehénlétszám hatása a fajlagos munkaidő-felhasználásra Forrás: (Vadász, 1965)

A bajai járás tejelő tehenészet mutatóinak értékei az 3. táblázat adatai szerint alakultak. A csökkenés szintén megfigyelhető az egy tehén gondozására jutó éves munkaóra tekintetében.

\begin{tabular}{|l|l|l|l|}
\hline Tehénlétszám db & $\begin{array}{l}\text { A vizsgált üzemek } \\
\text { száma }\end{array}$ & Átlagos tehénlétszám & $\begin{array}{l}1 \text { tehénre jutó } \\
\text { munkaidő évente (óra) }\end{array}$ \\
\hline $1-49$ & 3 & 15 & 390 \\
\hline $50-99$ & - & - & - \\
\hline 100 felett & 4 & 185 & 315 \\
\hline
\end{tabular}

3. táblázat A bajai járás tejelő tehenészeteinek munkaidő-felhasználása

Forrás: Saját kutatás (N=7), 2018

A fóbb feladatok dolgozói létszámszükséglet alakulását a 2. ábra mutatja be. Az ábráról leolvasható, hogy a kutatás során elemzett telepeken milyen arányban oszlanak meg létszámszükségletben a napi szinten elvégzendő feladatok. A tört számok azt jelzik, hogy egyes feladatokat átfedve látnak el, kisegítve egymást. Az ábrán nem tűntettük fel a 3 kisebb tehénlétszámmal rendelkező üzemet, mert véleményünk szerint ennél a méretkategóriánál a feladatkörök nincsenek szegmentálva, nincs úgynevezett szakosított munkarend. Ezeken a telepeken jellemzően néhány ember, jellemzően családtagok látják el az állatokkal kapcsolatos munkavégzést. Ezt a gondolatmenetet támasztja alá Gasson (1982) álláspontja is, miszerint a gazdálkodó szívesebben dolgozik együtt a családja tagjaival, mint más dolgozókkal. A családi vállalkozás további hozadéka, az, hogy a tőke nem válik szét, ugyanakkor egy külső munkaerőt alkalmazó vállalkozás esetében a munkaerő bérköltséget is jelent (Gasson - Errington, 1999). 


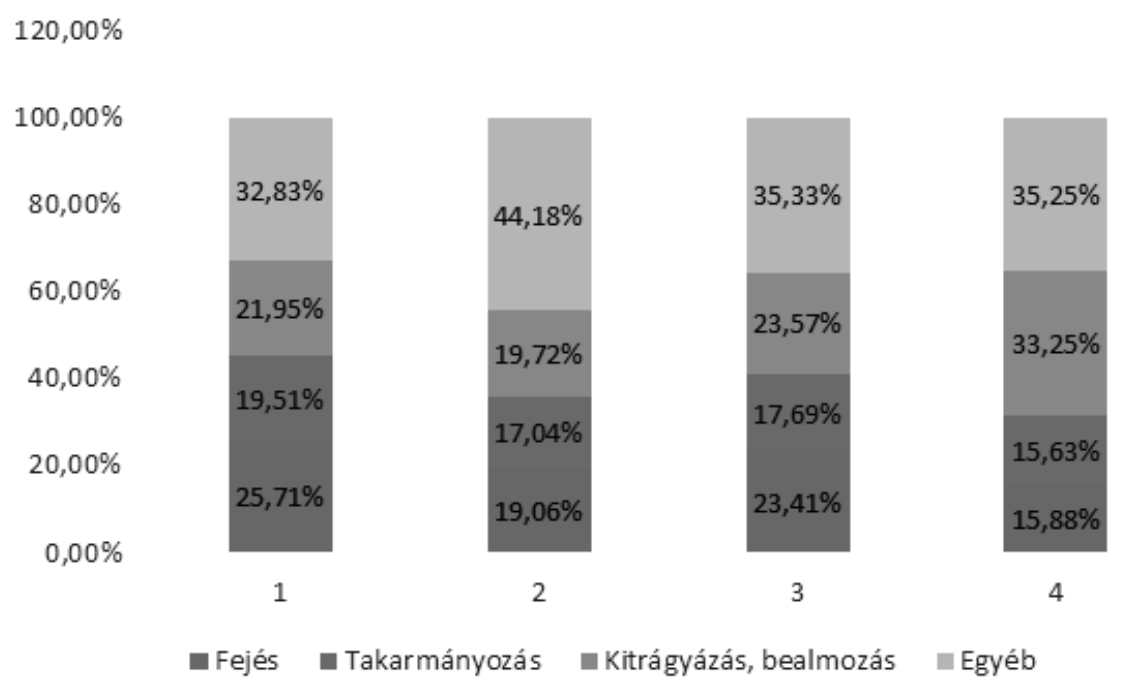

2. ábra Főbb munkamüveletek százalékos megoszlása a tehenészetekben (telepek szerint)

Forrás: Saját kutatás (N=7), 2018

\section{Emberi erőforrás jelentősége}

Napjainkban újraértékelődik,- felértékelődik az emberi erőforrásokkal való gazdálkodás. A vállalati gazdálkodás legfontosabb erőforrásaként a megfelelően motivált, értékes tudással és készségekkel rendelkező dolgozók nevezhetők. Az általuk végzett hatékony és eredményes munka segíti a szervezetet céljai elérésében, valamint a megfelelő piaci pozíció betöltésében. Az emberi erőforrás olyan sajátos termelési tényező, melynek véges a munkaerőpiacon lévő kínálata és az általa elérhető teljesítménye. Speciális kiváltásága továbbá még az is, hogy megújulásitanulási képességekkel rendelkezik, amit viszont nagymértékben befolyásol a munkavállalók egyéni motivációja (Magda et al, 1998). A motivált, produktívan dolgozó munkavállalók foglalkoztatásával nagymértékben generálható az adott szervezet piaci pozíciójának megszilárdítása. Abban, hogy egy szervezet elérje a megfelelő munkavállalók alkalmazását nagy segítséget nyújt egy jól működő HRM rendszer működtetése. Az emberi erőforrás menedzsment (HRM) egy többszörös cél által vezérelt és sok érintettel rendelkező szervezeti alrendszer, melynek alapvető gazdasági célja, hogy olyan költséghatékony munkaerő kezelési rendszert tudjon létrehozni és működtetni, ami a szervezetek számára pénzügyi előnyt és életképességet 
jelent (Karoliny- Poór, 2017). Fontos kiemelni még azt is, hogy az emberi erőforrás menedzsment tevékenységével komoly hatást gyakorol; az alkalmazottak munkahelyen végzett tevékenységére, támogatja az új munkavállalók beillesztését, csoportok kohéziós erejére pozitív hatást gyakorol, valamint fejleszti a munkahelyi légkört. Gondoskodik az alkalmazottak megbecsüléséről, anyagi illetve nem anyagi javadalmazásra annak formájára és mértékére tesz javaslatot (fizetésemelés, előléptetés, szakmai fejlődés, juttatások, döntésekbe való bevonás, szociális és egészségügyi támogatás) (Pálinkás- Vámosi, 1999).

Egy szervezet HRM tevékenységének külön ki kell térjen a dolgozói elégedettség érzetének vizsgálatára is, figyelemmel kíséri a munkafolyamatokat és a dolgozók fejlődését, valamint az operatív és a stratégiai célokat. A munkahelyi elégedettség az egyik legfontosabb viselkedésmód, amely arra vezethető vissza; hogy mennyire tartjuk kihívásokkal telinek a munkánkat, kielégítőnek találjuk-e a javadalmazás formáját- mértékét, valamint a munkafeltételek,- munkatársak,- vezetőség mennyire inspirál munkavégzésünk során (Bakacsi, 2000).

\section{Dél-alföldi régió és a bajai járás jellemzése}

A bajai járás a Dél-Alföldi régió területén helyezkedik el, amely Magyarország legnagyobb területű régiója; $18339 \mathrm{~km}^{2}$-rel az ország területének 19,6\%-át fedi le és az ország lakosságának 13\%-a él ezen a területen. A térség tipikus alföldi táj, a jó minőségü talajok és a kedvező éghajlati tényezők a magas napsütéses órák száma, a termálvíz gazdagság együttesen alakítják a régió mezőgazdasági termelésének alakulását és az erre épülő élelmiszeriparát. Mivel már évtizedek óta csökken a DélAlföld mezőgazdasági területén és az élelmiszergazdaságban foglalkoztatottak száma, ebben az ágazatban is felértékelődik a humán erőforrás. Fontos, hogy az ágazatban tevékenykedők felkészültsége, hozzáértése, szakképzettsége, iskolázottsága, innovatív készsége megfelelő legyen. Ezek alapján megállapítható, hogy a Dél-alföldi régióban elhelyezkedő mezőgazdasági vállalatok versenyelőnyének forrásául is a magasan képzett és motivált munkaerő, az alkalmazottak által végzett folyamatos fejlesztések és az új termelési rendszerekhez való rugalmas alkalmazkodása szolgál. Ezen felül pedig cél, hogy a munkavállaló bérének folyamatos emelkedése, elégedettségi érzetének megtartása mellett a meglévő kapacitását minél hatékonyabban használják ki a vállalatok és nem utolsó sorban a termelékenység olyan irányú növelésére törekedjenek, hogy az ne járjon együtt a munka monotonitásának növekedésével (Szepesi, 2006). 


\section{Anyag és módszertan}

Ahhoz hogy kutatásunk megfeleljen a tudományos kritériumoknak és egy teljesebb kép alakulhasson ki a vizsgált témával kapcsolatosan, kérdőíves kutatás módszerét alkalmaztuk (Babbie, 2008). A kvantitatív vizsgálat során véletlen mintavételezési eljárás során jutottunk adatokhoz, melynek lényege; $n<\mathrm{N}$ számú egyed egymást követő ismétlés nélküli választása történik meg, amely esetében minden egyes kiválasztáskor a sokaságban még meglévő elemek kiválasztása azonos valószínűséggel rendelkezik (Sajtos - Mitev, 2007). Kérdőívünket Google alkalmazásának és a telepeken való személyes megjelenés útján sikerült kitöltetni 188 fóvel. Az adatfelvétel időszaka 2018 augusztus és október között történt, célcsoportja pedig a bajai járásban lévő tejelő szarvasmarha ágazatban foglalkoztatottak voltak. Az alkalmazott adatfeldolgozás során a kitöltött kérdőívek kódolását a Microsoft-Excel táblázatkezelő program függvényeinek segítségével végeztük el. A kódolást követően, a meghatározott változók figyelembevételével az adatokat egy statisztikai elemző programba (SPSS-be) rögzítettük. Az adatok értelmezhető információvá alakítása során leíró statisztikát, kereszttábla lekérdezés alkalmazásával összefüggés vizsgálatot és klaszter analízist végeztünk el. Kiemelendő az analízis készítése, melynek célja, hogy a megfigyelt elemeket több változó alapján homogén csoportokba ossza fel. Olyan csoportok létrehozása a cél, amelyek csoporton belüli elemek között maximális a hasonlóság, valamint a csoportok között maximális a különbözőség. Nem az egyediség, hanem a jellegzetes, az általánosíthatóság mutatható ki. Fontos kiemelni, hogy a kérdőívet kitöltők között a föiskolai,- egyetemi végzettséggel rendelkezők aránya nagyon alacsony volt, ezért ezeket az adatokat elemzésünk során nem tudtuk érdemlegesen felhasználni. Kérdőíves kutatásunk nem reprezentatív, mivel a reprezentativitáshoz szükséges kritériumoknak nem felel meg, ezáltal az eredmények csak tendenciákat mutatnak.

\section{Eredmények}

Az eredményeinket két darab hipotézis megfogalmazásának segítségével szeretnénk ismertetni.

A vizsgált sokaság azon munkavállalói esetében, akik úgy nyilatkoztak, hogy nagymértékben leterheltnek érzik magukat munkavégzésük során, kevésbé szándékoznak 1-2 éven belül elhagyni munkahelyüket, mint azon munkavállalók, akik kisebb mértékben érzik magukat leterheltnek munkahelyükön. 
Többek között azért is fogalmaztuk meg ezt a hipotézist, mert az ágazaton belül szerzett információink-, tapasztalataink alapján azt a trendet véltük felfedezni, hogy a nagymértékben leterhelt,- leterheltséget érző munkavállalók kevésbé hagyják el munkahelyüket, mint a kis mértékben leterhelt-, leterheltséget érző kollegáik. A kérdőíves kutatásba vont sokaság válaszait kódolását követően az SPSS program segítségével egy kereszttábla lekérdezés alkalmazásával fogjuk vizsgálatba vonni. $\mathrm{Az}$ elemzés során megvizsgáljuk, hogy van-e összefüggés, és amennyiben van összefüggés abban az esetben értékeljük, hogy milyen irányú összefüggés alakul ki a foglalkoztatottak leterheltség érzetének mértéke és a munkahely elhagyási szándékuk között. A vizsgált adatok és kérdések között szignifikáns összefüggés tapasztalható, tehát az összefüggés vizsgálat kiértékelhető.

A 4. táblázat adatai alapján nyilvánvalóvá válik, hogy a kevésbé leterheltséget érző válaszadók közül 77,8\% szerint nem szándékozik 1-2 éven belül munkahelyet váltani. Továbbá a közepes leterheltséget érző válaszadók közül is 69,8\%-a nyilatkozott úgy, hogy nem szándékozik munkahelyet váltani 1-2 éven belül. Hasonlóan alakul az érték a nagyobb leterheltséget érző válaszadók esetében is, 68,5\%-uk válaszolt nemlegesen a feltett kérdésre. A teljes mértékben leterheltséget érző válaszadók esetében 29,2\%-a nem szándékozik munkahelyet váltani, ugyanakkor ugyanilyen arányban gondolják úgy is, hogy munkahelyet fognak váltani 1-2 éven belül. Kiemelendő, hogy közülük 41,7\%-a gondolkozik a közeljövőben történő munkahelyváltás kérdésén.

Ezek alapján elmondható, hogy hipotézisünk csak részben teljesült. A közepes vagy nagyobb mértékü munkahelyi leterheltséget érzők többsége kevésbé gondolkodik el azon, hogy munkahelyet váltson 1-2 éven belül. A kevésbé leterheltséget érző válaszadók esetében nem figyelhető meg a biztos munkahely elhagyási válasz arányának jelentősebb növekedése. Viszont azon válaszadók esetében, akik teljes mértékű leterheltséget éreznek a munkahely elhagyási szándékának aránya megnövekedik és jelentősebb a munkahely elhagyási szándék megfontolása is. Így ez eltérő tendenciát mutat az összehasonlított két kategóriához képest. 


\begin{tabular}{|c|c|c|c|c|c|c|}
\hline \multicolumn{7}{|c|}{ Kereszttábla- elemzés } \\
\hline & & & \multicolumn{4}{|c|}{$\begin{array}{l}\text { Az utóbbi időben felmerült-e Önben, hogy a } \\
\text { következő 1-2 évben elhagyja munkahelyét? }\end{array}$} \\
\hline & & & Nem & $\begin{array}{l}\text { Gondolkozik } \\
\text { rajta }\end{array}$ & Igen & Összesen \\
\hline \multirow{10}{*}{$\begin{array}{l}\text { Mennyire } \\
\text { érzi magát } \\
\text { leterheltnek a } \\
\text { munkahelyén? }\end{array}$} & \multirow{2}{*}{ Egyáltalán nem } & Érték & 4 & 0 & 0 & 4 \\
\hline & & Százalék & $100,0 \%$ & $0,0 \%$ & $0,0 \%$ & $100,0 \%$ \\
\hline & \multirow{2}{*}{ Kis mértékben } & Érték & 14 & 4 & 0 & 18 \\
\hline & & Százalék & $77,8 \%$ & $22,2 \%$ & $0,0 \%$ & $100,0 \%$ \\
\hline & \multirow{2}{*}{$\begin{array}{l}\text { Közepes } \\
\text { mértékben }\end{array}$} & Érték & 37 & 12 & 4 & 53 \\
\hline & & Százalék & $69,8 \%$ & $22,6 \%$ & $7,5 \%$ & $100,0 \%$ \\
\hline & \multirow{2}{*}{ Nagymértékben } & Érték & 61 & 28 & 0 & 89 \\
\hline & & Százalék & $68,5 \%$ & $31,5 \%$ & $0,0 \%$ & $100,0 \%$ \\
\hline & \multirow{2}{*}{ Teljes mértékben } & Érték & 7 & 10 & 7 & 24 \\
\hline & & Százalék & $29,2 \%$ & $41,7 \%$ & $29,2 \%$ & $100,0 \%$ \\
\hline
\end{tabular}

\section{4. táblázat Munkahely elhagyási szándék és a leterheltség érzet mértéke közötti} összefüggések

Forrás Saját kutatás (N=188), 2018

A vizsgált sokaság esetében a foglalkoztatotti elégedettség érzete által élesen elkülönithetö a szakmunkás-, szakiskolai végzettséggel rendelkezök elégedettségi érzete a más végzettséggel rendelkezökéhez képest.

A második hipotézis megfogalmazásának eredendő oka, a szakmunkás végzetséggel rendelkezők hiánya az ágazaton belül, amely az egyik olyan szűk keresztmetszet, ami már a közeljövőben érezteti negatív hatását. Ennek megfelelően a szervezeteknek komoly feladatot jelent a megfelelő szakmunkás végzettséggel rendelkezők felvétele és megtartása, amely tudatos és módszeres HR politikát és megfelelő vezetői stílust igényel.

Hipotézisünk igazolásához az SPSS programcsomag segítségével elvégeztünk egy klaszteranalízist, amelyben K-közép nem hierarchikus módszert alkalmaztunk. Ezen módszer során 3 klasztert határoztunk meg.

A hüvelykujj szabályok közül, melyeket több szakirodalom is javasol a klaszterek relatív mérete alapján történő, kutatás szempontjából fontos szegmens kijelölését és vizsgálatba vonását vettük alapul. A minimum 3 klaszter kialakítására pedig azért van szükség, mert a csak egy-két klaszterből álló klaszteranalízis nem értelmezhető, vizsgálható (Sajtos - Mitev, 2007). 
A létrejött 3 klaszter és a munkavállalók legmagasabb iskolai végzettség eloszlása közötti összefüggés vizsgálatát az alábbi táblázatban szemléltetjük.

\begin{tabular}{|c|c|c|c|c|c|c|}
\hline \multicolumn{7}{|c|}{ Mi az Ön legmagasabb iskolai végzettsége? } \\
\hline & & & \multicolumn{3}{|c|}{ Cluster Number of Case } & \multirow{2}{*}{ Total } \\
\hline & & & 1 & 2 & 3 & \\
\hline \multirow{16}{*}{$\begin{array}{l}\text { Mi az Ön } \\
\text { legmagasabb } \\
\text { iskolai } \\
\text { végzettsége? }\end{array}$} & \multirow{3}{*}{$\begin{array}{l}8 \text { általánosnál } \\
\text { kevesebb }\end{array}$} & Érték & 13 & 1 & 17 & 31 \\
\hline & & \begin{tabular}{|l}
$\begin{array}{l}\text { Százalék } \\
\text { (sor) }\end{array}$ \\
\end{tabular} & $41,9 \%$ & $3,2 \%$ & $54,8 \%$ & $100,0 \%$ \\
\hline & & \begin{tabular}{|l} 
Százalék \\
(oszlop)
\end{tabular} & $21,0 \%$ & $2,9 \%$ & $18,5 \%$ & $16,5 \%$ \\
\hline & \multirow{3}{*}{ Általános iskola } & Érték & 24 & 8 & 13 & 45 \\
\hline & & \begin{tabular}{|l}
$\begin{array}{l}\text { Százalék } \\
\text { (sor) }\end{array}$ \\
\end{tabular} & $53,3 \%$ & $17,8 \%$ & $28,9 \%$ & $100,0 \%$ \\
\hline & & $\begin{array}{l}\begin{array}{l}\text { Százalék } \\
\text { (oszlop) }\end{array} \\
\end{array}$ & $38,7 \%$ & $23,5 \%$ & $14,1 \%$ & $23,9 \%$ \\
\hline & \multirow{3}{*}{$\begin{array}{l}\text { Szakmunkás, } \\
\text { szakiskola }\end{array}$} & Érték & 20 & 11 & 30 & 61 \\
\hline & & \begin{tabular}{|l}
$\begin{array}{l}\text { Százalék } \\
\text { (sor) }\end{array}$ \\
\end{tabular} & $32,8 \%$ & $18,0 \%$ & $49,2 \%$ & $100,0 \%$ \\
\hline & & \begin{tabular}{|l} 
Százalék \\
(oszlop)
\end{tabular} & $32,3 \%$ & $32,4 \%$ & $32,6 \%$ & $32,4 \%$ \\
\hline & \multirow{3}{*}{ Érettségi } & Érték & 5 & 14 & 25 & 44 \\
\hline & & $\begin{array}{l}\begin{array}{l}\text { Százalék } \\
\text { (sor) }\end{array} \\
\end{array}$ & $11,4 \%$ & $31,8 \%$ & $56,8 \%$ & $100,0 \%$ \\
\hline & & $\begin{array}{l}\begin{array}{l}\text { Százalék } \\
\text { (oszlop) }\end{array} \\
\end{array}$ & $8,1 \%$ & $41,2 \%$ & $27,2 \%$ & $23,4 \%$ \\
\hline & \multirow{4}{*}{$\begin{array}{l}\text { Főiskola, } \\
\text { Egyetem }\end{array}$} & Érték & 0 & 0 & 7 & 7 \\
\hline & & \begin{tabular}{|l}
$\begin{array}{l}\text { Százalék } \\
\text { (sor) }\end{array}$ \\
\end{tabular} & $0,0 \%$ & $0,0 \%$ & $100,0 \%$ & $100,0 \%$ \\
\hline & & \begin{tabular}{|l}
$\begin{array}{l}\text { Százalék } \\
\text { (oszlop) }\end{array}$ \\
\end{tabular} & $0,0 \%$ & $0,0 \%$ & $7,6 \%$ & $3,7 \%$ \\
\hline & & & & & & \\
\hline
\end{tabular}

5. táblázat: Klaszterek és az iskolai végzettség közötti összefüggésvizsgálat eredménye Forrás Saját kutatás (N=188), 2018 
Az 5. táblázatban szereplő adatok alapján elmondható, hogy az első klaszterben a szakmunkás,- szakiskolai végzettségü munkavállalók közel 32,2\% részesedéssel szerepelnek, az általános iskolai végzettségüek pedig 38,7\%, vagyis nem lehetséges a végzettség szerinti éles elkülönítés ezen a klaszteren belül. A második klaszterben a szakmunkás,- szakiskolai végzettséggel rendelkezők 32,4\% részesedési aránnyal képviseltetik magukat, míg az érettségizettek 41,2\%-al, az általános iskolai végzettségűek pedig megközelítőleg 23\% részesedéssel szerepelnek. Az adatok alapján nincs éles elkülönülés ebben a klaszterben sem. A harmadik klaszter vizsgálata során a 8 általános alatti-, az általános iskolai-, és az érettségi végzettséggel rendelkezők mindmind megközelítőleg 20\%-os részesedési aránnyal rendelkeznek, míg a legnagyobb aránnyal 32,4\%-al a szakmunkás,- szakiskolai végzettségűek szerepelnek. Azonban ez a különbség sem mondható érdemlegesnek, így ebben a klaszterben sem lehet a mutató szerint különbséget tenni. Ezek alapján egyértelműen kijelenthető, hogy a foglalkoztatotti elégedettség érzete által nem lehetséges elkülöníteni a szakmunkás,szakiskolai végzettségű munkavállalók csoportját, tehát a megfogalmazott hipotézisünk nem teljesül.

\section{Következtetések és javaslatok}

A vizsgálatba vont bajai járás tejelőtehenészeteiben foglalkoztatottak, akik nagyobb mértékü munkahelyi leterheltséget éreznek. kevésbé gondolkodnak el azon, hogy munkahelyet váltsanak 1-2 éven belül. Ennek az inkonzisztens eredménynek a jelentősége azért is kiemelendő, mert a szervezetek teljesítménye nagymértékben függ a foglalkoztatottak hatékonyságától. Azáltal, hogy a munkavállaló munkája során nagymértékű leterheltséget érez, munkavégzéssel kapcsolatos elégedettségi érzete is csökken. Ezzel párhuzamosan, pedig csökken a munkavégző produktivitása, precizitása, ami pedig termelés kieséshez vezet a szervezetek számára. Ennek megelözéséért fontos a foglalkoztatottak ösztönzése, motivációjuk fenntartása, elégedettségi érzetük növelése, leterheltség érzetük csökkentése. Az ágazatban leggyakrabban alkalmazott ösztönzési forma az anyagi juttatás, ezen belül is a fizetésemelés-, prémium. Ugyanakkor véleményem szerint a foglalkoztatottak magas fokú leterheltségét csökkenteni, ezzel párhuzamosan pedig az elégedettségi érzetét, motivációját növelni lehetne a folyamatos visszajelzések nyújtásával, munkájuk rendszeres értékelésével,- átszervezésével, ezáltal pedig elérhetővé válna produktivitásuk növelése.

A szakmunkások foglalkoztatotti elégedettségének növelése érdekében tett különböző elégedettséget befolyásoló tényezők és faktorok javítása a szervezeti hierarchiában horizontálisan a velük egy szinten elhelyezkedő munkavállalók számára 
is hasonló mértékű elégedettségi érzet növekedést okoz. Az előbbiekben említett összefüggés miatt a vezetők számára levonható következtetés, hogy a szakmunkás hiány megszüntetésére irányuló törekvések között a foglalkoztatotti elégedettség növelésére vonatkozó cselekvések a szervezet számára az egyik leghatékonyabb döntésnek bizonyul, mivel a különböző tényezők tartalmaznak olyan a teljes szervezeti rendszert átható és mindenkire befolyást gyakorló eszközöket, amelyekkel holisztikusan növelhető a foglalkoztatottak elégedettségi érzete.

\section{Hivatkozott források}

[1.] Babbie E. (2008): A társadalomtudományi kutatás gyakorlata. Budapest, Balassi Kiadó, 336-342. o.

[2.] Bakacsi G. (2000): Szervezeti magatartás és vezetés. Budapest, KJK Kiadó, 353. o.

[3.] Gasson M. (1982): The Entrepreneur: An Economic Theory. Martin Robertson, Oxford 124.o.

[4.] Gasson R. - Errington A. (1999): A családi gazdálkodás, a tőke és az állam szerepe In: Családi farmgazdaság. Szerk. Nábrádi A., Mezőgazdasági Szaktudás Kiadó, Budapest, 66.o.

[5.] Geszti Sz., - Borbély Cs. (2004): A magyar tejtermelő telepek munka-és termőföld termelékenységének elemzése és nemzetközi összehasonlítása. Gazdálkodás. XLVIII. évf. 6.sz. 32-46.o.

[6.] Horváth J. (2004): Tejtermelő tehenészeti telepek műszaki-technológiai feltételei. Gazdálkodás. XLVIII. évf. 5.sz. 60-66. o.

[7.] Husti I. (2003): Mezőgazdasági vállalkozásaink gépesítésének ökonómiai problémái. Agrárgazdaság, Vidékfejlesztés és Agrárinformatika az évezred küszöbén (AVA) Nemzetközi konferencia. Debrecen, 134.o.

[8.] Illés B. Cs., - Dunay A. - Markó O. (2014): A hazai állattenyésztő ágazatok versenyképességének változása. In: „Faculty of Agricultural and Environmental Sciences, Institute of Animal Husbandry, Animal welfare, ethology and housing systems", SZIE-GTK, Gödöllő, 6. o.

[9.] Kapronczai, I. (2011): A magyar agrárgazdaság az EU-csatlakozástól napjainkig. Budapest, Szaktudás Kiadó Ház Rt., 199. o.

[10.] Karoliny. M.-né. - Poór. J. (2017): Emberi erőforrás menedzsment kézikönyv Rendszerek és alkalmazások. Budapest, Wolters Kluwer Kiadó, 28- 30. o.

[11.] Kovács G. (2010): A mezőgazdasági szektor nemzetgazdasági jelentősége. Herman Ottó Intézet Nonprofit Kft., Gazdálkodás Agrárökonómiai tudományos folyóirat, 54. évf. 5. sz. 17. o. 
[12.] KSH (2019): Magyar Statisztikai Évkönyv 2017, Letöltés dátuma: 2019. február 25, forrás: www.ksh.hu:

http://www.ksh.hu/docs/hun/xftp/idoszaki/mezo/mezoszerepe17.pdf

[13.] KSH (2019): Magyar Statisztikai Évkönyv 2017, Letöltés dátuma: 2019. március 5, forrás: www.ksh.hu:

http://www.ksh.hu/docs/hun/xstadat/xstadat_evkozi/e_oma004.html

[14.] Magda S. - Hajós L.- Dolmány F. (1998): A munkaerő gazdaságtana. Budapest, Dinasztia Kiadó, 52-56., 89-95. o.

[15.] Pálinkás J. - Vámosi Z. (1999): Emberi erőforrás menedzsment. Budapest, LSI Oktatóközpont A Mikroelektronika Alkalmazásának Kultúrájáért Alapítvány, 97-98. o.

[16.] Sajtos L. - Mitev A. (2007): Spss Kutatási és Adatelemzési Kézikönyv. Budapest, Alinea Kiadó, 32-33., 45-47. o.

[17.] Stefler József - Holló István - Iváncsics János - Dohy János - Boda Imre - Bodó Imre - Nagy Nándor (1995): Szarvasmarha-tenyésztés. In.: Állattenyésztés I. Szerk.: Horn Péter. Mezőgazda Kiadó, Budapest, 10. o.

[18.] Szepesi Z. (2006): Az értékteremtő folyamatok menedzsmentje- termelés, szolgáltatás, logisztika. Budapest, Aula Kiadó, 243-244. o.

[19.] Vadász L. (1965): A munkatermelékenység növelése a tehenészetben. Mezőgazdasági Kiadó, Budapest, 36.o.

\section{Szerzők:}

\section{Gulyás Dóra Kinga}

Szent István Egyetem

Számviteli Tanszék

dkgulyas@gmail.com

\section{Fodor Fanni Ildikó}

Szent István Egyetem

Mikroökonómiai Tanszék

fodor.fanni@gtk.szie.hu

\section{Thalmeiner Gergő}

Szent István Egyetem

Vezetés és szervezés MSc.

II. évfolyam

thalmeiner.gergo@gtk.szie.hu 